\title{
Questions of General Pedagogy in Higher Education
}

\section{Cuestiones de la pedagogía general en la educación superior}

\author{
Olga L. Shepelyuk
}

Tyumen Industrial University, Russia

ORCID: https://orcid.org/0000-0001-9170-2232

Received 02-12-20 Revised 02-25-20 Accepted 06-13-20 On line 06-29-20

*Correspondence

Email: uni.state-2019@yandex.ru

\section{Cite as:}

Shepelyuk, O.L. (2020). Questions of General Pedagogy in Higher Education. Propósitos y Representaciones, 8 (SPE2), e646.

http://dx.doi.org/10.20511/pyr2020.v8nSPE2.646 


\section{Summary}

At present, the growth of individual independence and activity, the change in its orientations and values requires changes in the issue of professional. The article carries out a serious study on the importance of general pedagogical concepts in modern Russian society. General issues of pedagogy determine the conceptual significance of the pedagogical process as a whole. In the article, the author formulates the concept of education in a broad social sense, reveals its pedagogical essence, describes the characteristic properties. Also, through the prism of such a science as pedagogy, the author expands and considers such categories as teaching, didactics, and identifies his author's aspects of understanding these categories. An important issue in the article is the relationship of pedagogy with other sciences, which are its methodological basis.

Keywords: Pedagogy; Modern Society; Education; Transfer of Experience; Professional Education.

\section{Resumen}

En la actualidad, el crecimiento de la independencia y la actividad individual, el cambio en sus orientaciones y valores requiere cambios en el tema profesional. El artículo lleva a cabo un estudio serio sobre la importancia de los conceptos pedagógicos generales en la sociedad rusa moderna. Las cuestiones generales de la pedagogía determinan la importancia conceptual del proceso pedagógico en su conjunto. En el artículo, el autor formula el concepto de educación en un sentido social amplio, revela su esencia pedagógica, describe las propiedades características. Además, a través del prisma de una ciencia como la pedagogía, el autor expande y considera categorías tales como la enseñanza, la didáctica e identifica los aspectos de su autor para comprender estas categorías. Un tema importante en el artículo es la relación de la pedagogía con otras ciencias, que son sus bases metodológicas.

Palabras clave: Pedagogía; Sociedad Moderna; Educación; Transferencia de Experiencia, Educación Profesional.

\section{Introduction}

One of the most important characteristics of any science is its connection with other sciences. Interconnection serves as the most important source of the development of sciences and is presented in three aspects: firstly, some sciences, in relation to others, carry out ideological and methodological functions; secondly, the content of the scientific knowledge of some sciences helps others to penetrate deeper into the subject of research; thirdly, in the process of the interconnection of sciences, they are enriched by methods of scientific research.

Pedagogy is often referred to as the activities of educating, or instructing or teaching, the activities that impart knowledge or skill. The Oxford English dictionary (2002) defines pedagogy as the profession, science or theory of teaching. Watkins and 47 Mortimore refer to 'pedagogy' as derived from French and Latin adaptations of the Greek word for 'boy' and 'leader', meaning a man having oversight of a child. Defined in this way, pedagogy is seen as the art and science of teaching children. To distinguish between adult learning and child learning, Knowles proposed a new theory of adult learning, which he termed andragogy. 'Andr' means 'man' thus andragogy is a suitable term for the science and art of helping adults to learn Knowles cast doubt on the appropriateness of applying the term pedagogy to the teaching of adults. As for the more commonplace term, pedagogy, Simon, in his article 'No Pedagogy in England?' deplores English unwillingness to use a word that he claims, holds an honoured place, in the educational tradition of the European Continent. Simon believes that this stems back to the work of Comenius in the seventeenth century. Simon, places the responsibility for English unhappiness with the idea of a 
science of teaching on the elitist, class-dominated private school tradition, which he believes to be a peculiarly English characteristic. Simon asserts that this is why education, as a subject of enquiry and study, has had little prestige in England. Levine makes the same point without entering into any comparative historical explanation.

The study of many pedagogical problems requires an interdisciplinary approach, data from other human sciences. Therefore, pedagogy cannot develop separately and has strong ties with various branches of human knowledge, occupying an important place in the system of humanitarian knowledge and human sciences. Among the first were the relations of pedagogy with philosophy and psychology, which are an important condition for the development of pedagogical theory and practice.

Like any science, pedagogy has its own terminological apparatus. During the formation of pedagogy as a science, three basic concepts of pedagogy were defined - "education", "training", "education".

"Education" as a general category historically included "training" and "education". Education is an eternal category, exists from the moment of the emergence of mankind (Ronamov, 2013). On the other hand, the goals and content of upbringing have changed in the course of history (for example, the goals of upbringing in a primitive society are not suitable for solving the problems of upbringing of the Renaissance).

Parenting is defined in different ways. However, for all definitions, the following symptoms are characteristic:

- targeted impact on the pupil;

- these actions have a social context (transfer of ZUNs, ideas, social experience, ways of behavior);

- conditions are created for mastering the norms of relations;

- a person masters a complex of social roles.

There is a narrow sense of this concept and a wide one. Parenting is a focused and organized process of personality formation. In pedagogy, the concept of "education" is used in the "wide and narrow" social, as well as in the "wide and narrow" pedagogical sense.

Higher education institutions have a training mission that should be remembered, not so much to analyze it in itself as to show its implications for pedagogy. It is therefore from the pedagogical point of view, as defined above, that one looks at the mission of training higher education, which combines fundamental training and specialization, is expressed in the training programs, opens up research activities. This article has four sections. The first describes the common mission of higher education of CNRST and universities and shows the need for inseparable competences among teachers. The second outlines the main components of basic training and explains the proper educational issues. The third focuses on the curriculum and the program approach that puts more and more forward to higher education and identifies the educational implications of this approach. The fourth relates to research and explains what can be pedagogy of the training of researchers. The CNRST and the university share a common mission of higher education. This means that they also share common requirements for the educational act. In a quite appropriate sense, one can therefore speak of pedagogy of higher education which takes root in the missions of university training. 


\section{The common higher education mission}

The CNRST and the university have a common mission of higher education. The discussion and analysis contained in a previous Council opinion, based on a report by the Committee on Higher Education and which implicitly laid down the anchors of this document, should not be repeated here. There are historical, legislative, administrative and pedagogical roots which undoubtedly invite us to consider that CNRST shares with the university a common mission of higher education. Suffice it to recall that the creation of the CNRST is interpreted as an original version of a vast movement aimed at providing post-secondary education shorter than university education, capable of preparing for the performance of higher-level technical functions, is the professional component of the mission of the CNRST and called a short higher education. On the other hand, we are also thinking more and more, and this joins the preuniversity component of the CNRST mission; that CNRST and university should be considered as two institutions which, in common and in continuity, administer a long training program, which ideally belongs to a single curriculum of higher education. Specifically, the mission of higher education is expressed in the fundamental training concepts, general education and specialization. In fact, it is indeed a balance between these elements of formation. And it is a dynamic equilibrium, indeed, since higher education ultimately aims at access to a specialization, but a specialization that allows us to situate a field of disciplines in relation to all the universes of knowledge and which attaches to the very foundations of Paper this discipline. But specialization lies precisely in the mastery of a discipline; general education, in the capacity to relativize this discipline and situate it in relation to all the universes of knowledge and the major fields of culture; and basic training in the appropriation of ideological, historical and methodological of this discipline. It is understood that the equilibrium of the elements is dynamic and that their dosage can and must vary, depending on whether it is pre-university training or technical training at CNRST, the first, second or third cycle at university. The mission of higher education is also expressed in the concepts of teaching, research and service to the community. Of course, whether it is a question of one or the other of these functions, it is ultimately training. And the university is called to consolidate the achievements of college education, both in the pursuit of its own objectives and in a spirit of teaching inter-orders collaboration. Here, too, there are variable equilibrium, particularly between teaching and research, at both levels of education. The three functions are therefore fulfilled differently, depending on whether they are the CNRST or the university. For example, at the second and third university levels, research are inextricably linked to education, with the training of the student being pursued in both research and teaching. And while the research mission is not formally enshrined in the College Act, research does exist in college not only as a tool for collective development, but also as a tool for training high school students. If the high research potential of college professors is to be more widely recognized and used in the future, it is expected that the teaching function will be more valued and supported at the university level. There is, in fact, only one mission of higher education, but there are specificities which must be recalled briefly.

As a corollary to the massification of access and participation over the past half century, higher education systems have experienced an increase in higher education providers, with a burgeoning of new HEIs established across the globe to respond to growing demand. As a matter of fact, the majority of HEIs operating today were established in the past century (Guri-Rosenblit and Sebkova, 2004). To illustrate the magnitude of change, the Indian higher education system consisted of 27 universities and 695 colleges at the time of independence in 1949 (Agarwal, 2009). By 2006, the number of HEIs had sky-rocketed to 361 universities and thousands of colleges (Kapur and Crowley, 2008). This trend is unlikely to abate with the further growth in total enrolments projected for the next 15 years. To put figures in perspective, Daniel (2009) estimates that meeting the demand for an additional 85 million students worldwide between 2010 and 2025 will require accommodating an additional 109000 students - i.e. the equivalent of four large universities - every week! In many countries, the massification process has led to the emergence of new types of institutions within higher education, as alternatives to traditional universities. The growth of a strongly employer-oriented non-university sector, closely integrated with the labour 
market needs of each locality and region, is indeed one of the most significant structural changes in recent times for higher education systems (Grubb, 2003; OECD, 2005a). Within the OECD, this movement started in France in the mid 1960s with the creation of Instituts Universitaires de Technologie (IUTs) based on the model of some of the United States' vocationally-oriented junior and community colleges, followed in the early 1970s by Technical and Further Education Colleges (TAFE) in Australia, Fachhochschulen in Germany and Distriktshøgskoler in Norway. In the late 1970s, Portugal set up Polytechnic Institutes while the Netherlands created its Hogescholen (HBO) in the late 1980s. The 1990s saw the emergence of the Polytechnic sector (AMK) in Finland, the Universidades Tecnológicas in Mexico and the Swiss Universities of Applied Sciences. Finally, the Universidades Politécnicas and Universidades Interculturales emerged over the past decade in Mexico (OECD, 2008). These new HEIs were often established to create training opportunities for mid-level professionals needed for post-industrial and increasingly knowledge-intensive economies (Altbach et al., 2009). By offering shorter programmes, they were better able to meet growing demands at a manageable cost (Trow, 1974). They were also able to respond to increasingly diverse needs of the labour market and regional development (Kyvik, 2004), and to accommodate the growing diversity of individual students' motivations, expectations and career plans (Goedegebuure et al., 1994). Assessing the relative importance of each sector is not straightforward as there is no exhaustive register of HEIs worldwide, new providers are being established almost on a weekly basis, and the non-university sector is far from being homogenous. Nevertheless, the latest estimates of the UNESCO-affiliated International Association of Universities (IAU) list over 17000 HEIs worldwide (IAU, 2013).

Several countries have also relied extensively on private providers to meet the growing demand for higher education, resulting in a massive expansion of the number of private HEIs. This trend has been most prevalent wherever there has not been a tradition of public funding of higher education, or resources have been limited to accommodate any additional demand through public higher education (Levy, 2008; Bjarnason et al., 2009). The fastest-growing systems have also been those in which private provision has expanded most rapidly. For instance, the private sector in India, which accounted for just $15 \%$ of the seats of engineering colleges in 1960, rose to nearly 87\% of seats by 2003 (Kapur and Crowley, 2008). In Latin America, the past two decades have also seen the growing privatisation of higher education to balance resources with the need to satisfy increasing demand (Segrera, 2010). In 2008, Gürüz estimated that the private sector accounted for some $30 \%$ of enrolments worldwide (Gürüz, 2008). However, this average reflects diverse country-specific realities. Within the OECD, Chile, Japan and Korea have the largest private university sectors with fewer than $30 \%$ of students enrolled in public HEIs. Mexico, Poland, Portugal and the United States also have sizeable private sectors operating with dominant private funding in the university sector, while Estonia, France, Norway and Switzerland have significant non-university private sectors (OECD, 2012b). Outside the OECD, the largest private sectors are found in Asia (Indonesia, Philippines, Malaysia) and Latin America (Brazil), and to a lesser extent in some post-communist countries (Altbach et al., 2009). Private enrolments are likely to expand further in the years to come given the large projected increases in higher education participation in China and India, and the reliance of these countries upon private providers to absorb excess demand.

\section{Materials and Methods}

Research methodology. This problem was dealt with by many learned educators. Pedagogical research is carried out to cognize the objective pedagogical reality, explain, predict its development. Pedagogical research is a process and the result of scientific activity aimed at obtaining new knowledge about the laws of training, upbringing and education, their structure and mechanisms, content, principles and technologies. Pedagogical research can have a theoretical and experimental character. Balandov K.G., Zubanov V.P., Svinarenko V.G. dealt with this issue. 
Researchers such as Mordasova E.I., Povzun V.D., Sidorova N.N. considered issues of pedagogy from the perspective of the emotional sphere. Emotional intelligence is essential for modern man for successful communication in society.

Orunbaev U.B., Turdikulova B. studied the issues of general pedagogy from the position of national pedagogy and ethnic principles of education.

Protopopova V.A., Romanov A.A. studied this topic from the perspective of organizing a management system and optimizing its structure. In their opinion, the organizational structure of the educational process plays a crucial role in ensuring the quality of education. The task of general pedagogy is seen by him precisely in this. A certain role is played by the provision of an appropriate education system for the most adequate correspondence to the realities of the time.

Selivanova Yu.V., Skvortsova V.O., Solovyova O.V., Shipova L.V., Rudenko G.V. considered this problem as a promising area of research from the point of view of practical implementation of the results when describing the education system as a whole or its individual structural elements aimed at improving them. It is practically impossible to implement the developed new model without appropriate theoretical support, development of regulatory legal acts, scientific and methodological support, which is not possible for an individual researcher. In this regard, issues of improving the quality of education are becoming increasingly relevant, the implementation of which is the use of the method of professional cooperation. Cooperation in pedagogy is considered as a system of methods and techniques of training and education based on the principles of humanism and a creative approach to personal development. The pedagogy of cooperation is one of the most comprehensive and richest pedagogical generalizations that have brought to life numerous innovative processes in education.

\section{Results}

In a broad social sense, education is the transfer of accumulated experience from older to younger generations. Under the experience understand knowledge, skills, ways of thinking, moral, aesthetic, legal norms, work experience, a system of specific national values, the experience of increasing material wealth, etc., both in organized forms (education system), and through natural assimilation in the result of intergenerational interaction and environmental impact (Protopopova, 2016).

Given this, parenting is characterized by several properties:

- it is an eternal category, an integral part of human existence; arose simultaneously with the emergence of society and disappears if society ceases to exist;

- education is a social category inherent only to people;

- upbringing is of a historical nature, since its purpose, objectives, content, methods, forms, like the entire pedagogical policy, do not remain unchanged, but develop, change, improve under the influence of experience and science;

- upbringing is of a national character, since it is carried out within the framework of a specific nation (particular nation) and is based on its language, history, culture, customs, and everyday life;

Having examined the concept of education in a broad social sense, we have not sufficiently clarified its concrete social, and even less so pedagogical essence. The fact is that upbringing the transfer of accumulated experience - is not only done by professional teachers in specially created educational institutions. In modern society there is a whole complex of institutions that direct their efforts to education - the family, the media, literature, art, law enforcement agencies. Therefore, the general concept of education requires narrowing and concretization (Rudenko, 2011). 
In a narrow social sense, education is understood as a deliberate impact on a person by socio-social institutions in order to form a certain system of knowledge, attitudes, beliefs, moral values, preparation for life.

With this, the question arises: it would be right to blame only the school and teachers for many failures of upbringing if the possibilities and forces of the upbringing influence of other social institutions are dominated by the limited opportunities of educational institutions (Ponomareva, 2013). It does not require special evidence to conclude that the success of upbringing is possible only if there is a clear coordination of the actions of all those involved in the upbringing of social institutions.

In a broad pedagogical sense, upbringing is a specially organized, purposeful and controlled influence of a team of educators on pupils with the aim of forming certain qualities in them, carried out in educational institutions and covers the entire educational process (Elina et al, 2015).

In a narrow pedagogical sense, education is a process and the result of educational work aimed at solving specific educational problems. In pedagogy, the concept of education is often used to denote the components of a holistic educational process. They say, for example, "mental", "moral", "aesthetic" education and the like (Orunbaev, \& Turdikulova, 2016).

The result of education - the pupil changes his understanding of the world and attitude towards people and himself.

The task of upbringing always expresses the historical need of society for preparing a generation capable of realizing certain social functions and social roles.

Learning (teaching) is the process of the formation and assimilation of knowledge, skills and methods of cognitive activity of a person. Learning is a two-way process carried out by a teacher (teaching) and a student (training, teaching). In the learning process, the tasks of education are realized. In accordance with them, as well as taking into account the state of science, technology, art, the characteristics of cognitive activity, mental processes, due to the age and preparation of students, the selection of content and teaching methods (Mordasova, 2011).

If we talk about the process, then learning is the interaction of a teacher and students. In this case, the teacher:

1) sets out - purposefully transfers knowledge, life experience, methods of activity, the basics of culture and scientific knowledge;

2) directs the process of assimilation of knowledge, skills and abilities;

3 ) creates the conditions for the development of the personality of students (memory, attention, thinking).

What actions does the student perform:

1) learns - takes possession of the transmitted information and performs educational tasks with the help of a teacher, together with classmates or independently;

2) tries to independently observe, compare, think;

3) takes the initiative in the search for new knowledge, additional sources of information (reference book, textbook, Internet), is engaged in self-education.

The third main category of pedagogy - "education" - is understood as: 
1) the value of the developing and society;

2) the process of training and education of a person;

3) as a result of the latter;

4) as a system - a set of educational (or training and educational) institutions within a specific city, region, country.

How do the three main categories of pedagogy relate in modern Russian society? There are different points of view on this issue, which is characteristic of the objective process of development of any science. For example, speaking about the study of modern youth, it can be noted that "a multidimensional direction of student research can be the study of the consequences of certain pedagogical reforms, the assessment of the negative experience of ill-conceived innovations in education. Thus, the abandonment of the educational function of the school at the end of the twentieth century twenty years later was clearly manifested in youth rejecting traditional values at the beginning of the 21 st century. Therefore, we have to talk about irreversible changes in the socio-psychological portrait of a modern young man in Russia, which are a direct result of omissions in educational policy" (Romanov, 2013).

Training, upbringing and education can be considered as a specially organized activity, the result of which is human development (Dementyev, 2013). In recent years, they talk about the interaction of teachers and students as a developing environment for one and the other. Education, training and education are combined in the pedagogical process.

Pedagogy, like any science, develops, constantly reviews and expands aspects of understanding its main categories, and in practice it is continuously enriched by the experience of education and training through the infinity and versatility of pedagogical creativity.

Nowadays, pedagogy is considered as a science of laws, namely, as principles, forms, methods of upbringing, training and education at different stages of a person's age development. One of the important points is the determination of the relationship between pedagogy and other sciences.

Pedagogical science is connected, perhaps even to the greatest extent, with philosophy, which acts as its methodological basis. For a long time, philosophy and pedagogy functioned as a holistic science of society and man. Pedagogy has come out of philosophy, it is philosophical knowledge that underlies the understanding of the problems of pedagogy (Vitchenko, 2016).

On the other hand, at a certain stage (in the 40-60s of the XX century), the philosophy of education and upbringing was singled out as an independent scientific direction. The philosophy of education should help with determining the optimal philosophical system for solving the problems of pedagogy, in concretizing philosophical concepts in solving problems of pedagogy (Vostroknutov, 2012).

Pedagogy and sociology are looking for ways to translate the generalized results of sociological research into specific educational tasks. These tasks are jointly performed by social institutions - the family, educational and cultural, social, political and state organizations.

Pedagogy is associated with the economy, solving the problems of the economics of education and the organization of economic education of modern man.

Of particular importance for solving the issues of training and education is psychology, and above all, Age and Pedagogy. The special connection between pedagogy and psychology was pointed out by the famous Russian teacher K.D. Ushinsky. He repeatedly said that psychology ranks first among the sciences in terms of importance for pedagogy.

There are several of the most important communication nodes of pedagogy and psychology. The main one is the subject of research of these sciences. Psychology studies the laws of the development of the human psyche, pedagogy develops methods, ways, means of 
education, personal development. Parenting, education, human training is inherently the development of the psyche. The second important point is the generality of research methods. The close connection of psychology and pedagogy is also evidenced by the interpenetration of the basic concepts of these sciences. Pedagogy uses psychological knowledge to identify, describe, explain, systematize pedagogical facts. One of the important manifestations of the relationship between pedagogy and psychology has been the formation of such an area of psychology as educational psychology (Balandov et al, 2015). Achievements of these sciences contribute to the development of pedagogy, allow to improve methods of education and training, to develop fields of knowledge related to pedagogy.

\section{Components of pedagogy}

Nowadays, pedagogy is understood as a system of human education sciences. In general pedagogy there are 4 levels: 1 . General principles of pedagogy; 2 . Theory of education; 3. Didactics; 4. School studies.

The general principles of pedagogy study and determine the content, forms, methods of teaching and educating a person. The theory of education studies and defines goals, objectives, methods, means, subjects of the educational process, predicts its result. Didactics - considers learning as a means of education and upbringing of a person through the unity of teaching and learning. School science is a section of pedagogy that studies the problems of managing the education system. Some authors, instead of the general principles of pedagogy, talk about the philosophy of pedagogy.

\section{Conclusion}

Thus, the issues of general pedagogy in modern Russian society are very important for the education of a modern person, his full socialization and comprehensive harmonious development. Speaking of socialization, one can point out the social, including moral, attitude to resolve issues related to the good of society, the development of the ideas of humanism and humanity.

Human relationships often depend on personal sympathies, and not just on a person's social status. Currently, the social boundaries between people are blurring more and more. Under these conditions, the role of general pedagogy is growing, building general concepts of development and the orientation of human potential in society

\section{References}

Balandov K.G., Zubanov V.P., Svinarenko V.G. (2015). Algunas cuestiones de la teoría de la socialización en pedagogía general, pedagogía social y pedagogía del deporte. Psicología, sociología y pedagogía, 12(51), 12-22.

Epkhieva M.K. (2013). Formación de valores espirituales y morales de la generación más joven en el espacio educativo de la universidad. Ciencia del vector de la Universidad Estatal de Togliatti, 4 (26), 228 - 231

Cuestiones de pedagogía general, historia de la pedagogía y educación. (2017) Ministerio de Educación y Ciencia de la Federación Rusa. Sucursal de FSBEI HPE "Universidad Estatal Rusa de Turismo y Servicio" en Pyatigorsk. Pyatigorsk,.

Mordasova E.I. (2010). A la cuestión de la importancia del desarrollo de la esfera emocional de la personalidad en general y la pedagogía musical. Problemas reales de la educación y la formación musical: historia, teoría, práctica, recopilación de artículos científicos. Ser. "Pedagogía y psicología musical" Bajo la dirección general de L. G. Sukhova; Tamb. estado musica ped. Instituto de ellos. S.V. Rachmaninov. Tambov, (pp. 21-34) 
Orunbaev UB, \& Turdikulova B. (2016). Cuestiones generales de la pedagogía tradicional de los pueblos kirguises y uzbekos. Noticias de las universidades de Kirguistán (pp. 149-151).

Povzun V.D., \& Sidorova N.N. (2017). Evaluación rítmica del trabajo de mejora de la salud en un jardín de infantes. Noticias de Ciencia y Educación, 6(3). 50-53.

Ponomareva M.A., \& Sidorova M.V. (2018). Psicología general y pedagogía. Respuestas a las preguntas del examen. Minsk,

Problemas reales de psicología y pedagogía, colección interuniversitaria de trabajos científicos: en 2 partes / Ministerio de Educación y Ciencia de la Federación de Rusia, Universidad Estatal Social de Rusia, Departamento de Psicología Social, Departamento de Pedagogía Social, Departamento de Psicología General y Psicología del Trabajo; consejo editorial: L.V. Mardakhaev. Moscú, 2015. Volumen 1

Protopopova V.A. (2016).Gestión de sistemas educativos. Rostov del Don.

Romanov A.A. (2017). Aumentar la motivación de los estudiantes para estudiar la historia de la pedagogía como un problema de la educación pedagógica moderna. Pedagogía nacional y extranjera, 2(11), 41-47.

Rudenko G.V. (2011). A la cuestión de los principios generales de la pedagogía. Uchenye Zapiski universiteta im. 6 (76), 139-142.

Selivanova Yu.V., Skvortsova V.O., Solovyova O.V., Shipova L.V. (2017). Cuestiones generales de la pedagogía correccional: sección 1. Oligofrenopedagogía. Saratov

Vitchenko OV (2016).Enfoques modernos para la organización del trabajo independiente de los estudiantes en educación vocacional. Rostov del Don, 